\title{
COMPETENCIES OF GERMAN LANGUAGE TEACHERS IN INDONESIA AND VIETNAM BASED ON COMMON EUROPEAN FRAMEWORK OF REFERENCE FOR LANGUAGES (CEFR)
}

\author{
Pratomo W. ${ }^{1)}$, Akbar K. S. ${ }^{1)}$ dan Le Hoai An²) \\ ${ }^{1)}$ Yogyakarta State University dan ${ }^{2)}$ Vietnam National University of Hanoi \\ email: pratomow@gmail.com
}

\begin{abstract}
This study aims to (1) identify and compare the language competencies of German language teachers in Indonesia and Vietnam, and (2) identify the factors attributable to their competency levels. This was a qualitative descriptive study. The data were collected by means of questionnaires. The study shows that, based on the CEFR, the competencies of German language teachers in Vietnam are in the B2 level, while those of German language teachers in Indonesia are in the B1 level. The low competencies of German language teachers in Indonesia are caused by the language attrition and the lack of opportunities to receive language training.
\end{abstract}

Keywords: German language competencies, teachers, language training

\section{KOMPETENSI BAHASA JERMAN GURU BAHASA JERMAN DI INDONESIA DAN VIETNAM BERDASARKAN KERANGKA BERSAMA EROPA UNTUK BAHASA (CEFR)}

\begin{abstract}
Abstrak
Penelitian ini bertujuan untuk (1) mengidentifikasi dan membandingkan kompetensi bahasa Jerman guru bahasa Jerman di Indonesia dan Vietnam, dan (2) mengidentifikasi faktor-faktor yang mempengaruhi tingkat kompetensi tersebut. Metode yang digunakan dalam penelitan ini adalah deskriptif kualitatif. Data diperoleh dengan kuesioner. Hasil penelitian menunjukkan bahwa, berdasarkan CEFR, guru bahasa Jerman di Vietnam berada pada tingkatan B2, sedang guru bahasa Jerman Indonesia berada pada tingkat B1. Penyebab rendahnya kompetensi guru bahasa Jerman Indonesia disebabkan antara lain oleh atrisi bahasa dan kurangnya kesempatan untuk mendapatkan pelatihan/penataran bahasa.
\end{abstract}

Kata kunci: kompetensi guru bahasa Jerman, guru, pelatihan bahasa

\section{INTRODUCTION}

At present, German is learned by approximately 50 million people in various countries. The Southeast Asia is one area that gives great attention to learning the German language. In many Southeast Asian countries, German language is generally studied in secondary schools. So far, the advancement of learning German in Southeast Asia tends to be determined by the country itself. That is why, the learning conditions in each country are not known to one another. For the success of a better learning process, it is necessary to have close cooperation and collaboration among universities in various ASEAN member countries.

In order to support the program, the Faculty of Languages and Arts, Yogyakarta State University is conducting 
a collaborative research with Vietnam National University of Hanoi. The theme of this research is a comparative study on German teacher competence in Indonesia and Vietnam. This article presents the result of the study and at the same time answers the question of how the comparison of German teacher competencies in Indonesia and Vietnam is, and what causes the high or low level of their language proficiency.

Considering the limitations in many respects, this study only covers the professional competence of German teachers, based on the Common European Framework of References for Languages (CEFR). Council of Europe's activities to promote linguistic diversity and language learning are carried out within the framework of this convention. Its Language Policy Division implements the agreed intergovernmental programs with a special emphasis on development policy. This work has emphasized communication, exchange, and intercultural awareness. The influential Waystage and Threshold learning objectives, first published in the 1970s (Van Ek and Trim, 1990a, 1990b), marked the beginning of Efforts to identify a set of European levels of language proficiency, work that culminated in the publication of the Common European Framework of References for Language (CEFR) (Council of Europe, 2001).

Little (2006) mentioned that in 1966 The Council of Europe published the Common European Framework of Reference for Languages (CEFR) in two draft versions in 1996 (Council of Europe 1996a, b). On the basis of feedback received from a wide range of users and potential users, the document was revised and commercially published in English and French, the two official languages of the Council of Europe, in 2001 (Council of Europe 2001a, b). A German translation followed almost immediately (Council of Europe 2001c), and within April 2006 the Council of Europe website, <http://www.coe.int>, reports that translations of CEFR has been done into 21 other languages.

The CEFR is intended to 'promote and facilitate co-operation among educational institutions in different countries', 'provide a sound basis for the mutual recognition of language qualifications', and 'assist learners, teachers, course designers, examining bodies and educational administrators to situate and co-ordinate their efforts' (Council of Europe 2001a:5f.)

Grum (2002) states that the goals of CEFR are, first, to facilitate cooperation among educational institutions all over the world; second, to validate or give legitimacy to the qualifying language; and third, to help the learners, teachers, curriculum developers, and educational institutions to obtain certification. This opinion was also supported by Kirchner (2012), who said: "This is important in particular in view of the fact that the CEFR has prevailed as the basis for the level of classification and assessment of foreign language skills in a European context".

The above policy has become an agreement of the Council of Europe to make standarization for language learners beyond the European countries, including the learners of German language. Starting from November 2001, CEFR has been recommended to validate the language proficiency. In the context of German language, CEFR is called Gemeinsamer Europäischer Referenzrahmen (GER). GER is a system created to facilitate equal and uniform criteria for teaching and learning German language as well as its assessment, and to make it possible for comparison. In general, the standard of language proficiency is divided as follows:

GER is divided into 3 group of competencies: A, B, and C, and are still in accordance with the previously applicable levels, i.e. basic level (Grundstufe), 
intermediate level (Mittelstufe) and upper/advanced level (Oberstufe). Level A, elementare Sprachverwendung as the basic level, is divided into two levels, namely A1 and A2. Level B, selbständige Sprachverwendung, as the intermediate of independent level, also consists of two levels, namely B1 and B2. Level C, the highest level, is called kompetente Sprachverwendung which means the advanced level. This level is also divided into two levels, namely $\mathrm{C} 1$ and C2. At each level, there are a certain criteria that must be obtained, designed in the form of can description, i.e. statements about what $I$ can do ... or Ich kann.

\section{RESEARCH METHOD}

This study was conducted both in Indonesia and in Vietnam. The subject of this study was teachers of German language in Indonesia, i.e. the German teachers in Yogyakarta Special Province and Central Java, and the German teachers in Hanoi and its vicinity in Vietnam. Samples for this study were taken using simple random sampling method, with 48 participants from Indonesia and 8 participants from Vietnam. This study is qualitative research with descriptive interpretative approach. Data were collected by means of questionnaires. All data were analyzed and then compared. Validity and reliability of the instrument was reached by expert judgment from German language expert in order to obtain valid data.

The respondents were given a questionnaire which contained statements to reveal their language proficiency/ competencies in reference to GER (CEFR). Based on the reference, German language proficiency is divided into six levels, i.e (from lowest to highest) A1, A2, $\mathrm{B} 1, \mathrm{~B} 2, \mathrm{C} 1$, and $\mathrm{C} 2$. According to the required competence, based on the curriculum of Yogyakarta State University (UNY), the graduates of S1 (bachelor/ undergraduate program) from German Language Department UNY should have the competency equivalent to CEFR B2$\mathrm{C} 1$. Therefore, the questionnaires were composed of competence from A1 to C1, with the details as follows: A1 consists of 10 statements, A2 consists of 14 statements, B1 consists of 18 statements, B2 consists of 10 statements, and $\mathrm{C} 1$ consists of 8 statements. Altogether, there are totally 60 statements.

In accordance with the description of the language skills developed in the CEFR, the research instrument contains a set of statements that the respondents must respond regarding to their language proficiency, both receptive and productive, oral and written. Respondents were asked to provide answers in the form of (1) ja (yes), which means that the respondent has the ability specified in the statement, (2) nein (no), which means that the respondent does not have the ability specified in the statement, and (3) weiß nicht (do not know), which means that the respondent does not know or hesitates whether or not he/she has the ability specified in the statement.

\section{RESULT AND DISCUSSION}

\section{A. Competencies of German Language Teachers in Indonesia}

There were 48 respondens of German Language Teachers in Yogyakarta Special Province (DIY) and Central Java. All respondents had obtained the academic qualification of S1, with the average teaching experience over 5 years. From the data, it is known that most of them had taken a course aimed to improve their German language skills, either in Indonesia or overseas, organized by various institutions such as the Goethe Institut, Language Center for Development and Empowerment of Teachers and Educational Staff (P4TK, Pusat Pengembangan dan Pemberdayaan Pendidik dan Tenaga Kependidikan, 
Bahasa), German Language Department UNY, or others.

Table 1. Respondent Self-Assessment based on Selbstevaluation Questionnaire who answered " $\mathrm{J} a$ "

\begin{tabular}{lccccc}
\hline Niveau & A1 & A2 & B1 & B2 & C1 \\
\hline Frequency & 459 & 569 & 566 & 188 & 114 \\
\hline Total & 46 & 40 & 31 & 18 & 15 \\
\hline Percentage & $95.6 \%$ & $84.6 \%$ & $65.5 \%$ & $38.2 \%$ & $30.6 \%$ \\
\hline
\end{tabular}

Table 2. Respondent Self-Assessment based on Selbstevaluation Questionnaire who answered "Nein"

\begin{tabular}{lccccc}
\hline Niveau & A1 & A2 & B1 & B2 & C1 \\
\hline Frequency & 12 & 46 & 138 & 182 & 171 \\
\hline Total & 1.2 & 3.9 & 8 & 18 & 22 \\
\hline Percentage & $2.5 \%$ & $6.8 \%$ & $15.9 \%$ & $37 \%$ & $45.9 \%$ \\
\hline
\end{tabular}

Table 3. Respondent Self-Assessment based on Selbstevaluation Questionnaire who answered "Weiß nicht"

\begin{tabular}{lccccc}
\hline Niveau & A1 & A2 & B1 & B2 & C1 \\
\hline Frequency & 9 & 57 & 160 & 122 & 87 \\
\hline Total & 0.8 & 4.1 & 9 & 12 & 11 \\
\hline Percentage & $1.9 \%$ & $8.5 \%$ & $18.5 \%$ & $24.7 \%$ & $23.3 \%$ \\
\hline
\end{tabular}

In Table 1 above, it can be seen that respondents who stated having the competence of A1 level were 46 people, which is equivalent to $95.6 \%$, followed then by A2 level with 40 people $(84.6 \%)$, B1 level with 31 people $(65.5 \%)$, B2 level with 18 people $(38.2 \%)$, and the highest competency of $\mathrm{C} 1$ level with 15 people $(30.6 \%)$. The data show quite a fair trend, where nearly all respondents (95.6\%) state to have the lowest level (A1), while the highest level (C1) is obtained by only 15 people $(30.6 \%)$. This indicates that respondents who have the higher competence also have the competencies of the lower level(s). Conversely, those who have the lower competence do not necessarily have the competencies of the higher level(s).
From Table 2 it is clear that respondents who answered nein means they were sure that they did not have the ability as specified in the statements in the questionnaire. The details are as follows: A1 level is 1 person, rounded from 1.2 $(2.5 \%), \mathrm{A} 2$ is 4 people $(6.8 \%), \mathrm{B} 1$ is 8 people $(15.9 \%), \mathrm{B} 2$ is 18 people $(37 \%)$, and $\mathrm{C} 1$ is 22 people $(45.9 \%)$. The data indicate that the higher the level of proficiency (C1), the greater the number of respondents who felt confident of not having such competencies specified in the statements.

Table 3 shows the respondents who answered weiß nicht, which means they were doubtful or might not understand the statement in the questionnaire. The numbers are as follows: A1 level is 0.8 person, rounded to one person $(1.9 \%), \mathrm{A} 2$ is 4 people $(8.5 \%)$, $\mathrm{B} 1$ is 9 people $(18.5 \%)$, B2 is 12 people $(24.7 \%)$, and C1 is 11 people $(23.3 \%)$. The data indicates that the higher the level of competence (C1), the greater the number of respondents who were hesitant or did not understand the statements in the questionnaire.

As mentioned above, according to the Common European Framework of Reference (CEFR) for Language, the level of proficiency or competence in German language consists of six levels, namely A1 (the lowest), followed by the A2, B1, $B 2, C 1$, and C2 (the highest). To further facilitate and provide a clearer picture on the perception of German language teachers in Yogyakarta and Central Java on their linguistic competence, the obtained data will be discussed based on each level.

Level A1 is the lowest level in German language proficiency skills. Considering that the teachers are to teach German at schools at the levels A1 to A2, it is a must that the teachers have the language proficiency above that level, i.e. they should at least obtain B2 level. Looking at the data, a question then emerges: why are there still some statements answered 
nein, which means that the respondents felt they lacked the ability specified in the statements. No matter how small the amount, $(2.5 \%$ i.e. 15 out of the total 650 score) it still made us wonder why there were still some teachers not mastering the material for the most basic level, A1.

It is further revealed that there were 10 respondents who gave answers nein to the certain statements specifying the competencies of A1 level. Even respondent number 6 gave nein answers 4 times at A1 level, which means, the respondent felt that $\mathrm{s} /$ he lacked the abilities specified in those statements. The statements with nein (no) answers from this respondent are statements number 7 and 9 in the instrument. Statement No. 7 reads "Ich kann einfache Wendungen und Sätze gebrauchen, um Leute, die ich kenne, zu beschreiben und um zu beschreiben, wo er/sie wohnt." which means 'I can use simple utterances and sentences to describe a person that I know and to describe where $\mathrm{s} / \mathrm{he}$ (the person) lives'. While the statement No. 9 reads "Ich kann ein Gespräch verstehen, wenn und sehr idling deutlich und wenn viele gesprochen wird gemacht werden Pausen" which means 'I can understand conversations conducted slowly and clearly and with a lot of pauses/stops'. To both statements there were three respondents who gave straight answer as nein, which means that they were sure they had no competence as what is specified in the statement; or alternatively, it was because they possibility did not understand the purpose of the statement.

For level A2, as has been predicted, the 'number of respondents who answered nein (no) increases, so does those who answered weiß nicht (do not know). However, even if the number of answers nein and wei $\beta$ nicht are combined, the total number is still far below the answer $j a$ (yes), which means that the overall majority of respondents still perceived themselves to have passed the competency level A2. There were some teachers who felt inadequate for the competencies specified in the statements. This should not happen, though, because A2 level is actually the level of competence they should have passed whatsoever. For example, statement No. 19, which reads "Ich kann ein sehr kurzes Kontaktgespräch führen, aber ich verstehe noch nicht genug, um das Gespräch selbst weiterzuführen." which means 'I can start a short/brief conversation but I cannot quite understand to be able to continue the conversation.' For this statement, there were 10 respondents who gave answers nein.

At the next Level B1, there were 566 $j a$ answers or $65.5 \%$ of the total 864 , while nein answers were as many as 138 $(15.9 \%)$ and weiß nicht answers were 160 $(18.5 \%)$. In this B1 level, the percentage of weiß nicht is higher than nein, and there are even 5 respondents giving weiß nicht answers 12 times from the total 18 statements, approximately 67 percent. If the weiß nicht and $j a$ answers are combined, the percentage will be $35 \%$. This is of course still considered to be high because the $\mathrm{B} 1$ level is in fact below the minimum level of competence desired/required for S1 (stratum 1) graduates. Examined more closely, the statements that many respondents supply answers nein or weiß nicht were those statements related to schreiben (writing skill), such as statement No. 30 which reads "Ich kann über persönliche Themen, die mich interessieren, einfache komplexe Texte schreiben." meaning "I can write a complex text of certain themes that are of private/personal interest to me,' and Sprechen (speaking skill), for example statement No. 37, which reads "Ich kann kurz meine Meinungen und Pläne erklären und begründen." meaning 'I can briefly explain my opinion and my plans, and I can convey the reason(s)'. Both of these competencies are the ones related to productive skills. 
In addition, at this B1 Level, some respondents gave more weißnicht answers than $j a$ answers to the corresponding statements. They are respondents no 1 , $15,16,33$, and 47 . It means that those respondents considered themselves not having the competence level B1. Another interesting thing is, the number of wei $\beta$ nicht answers at this Level B1 is more than to nein answers. By this it can be interpreted that for some sub skills, the respondents felt hesitant or were not fully confident whether or not they had the competencies specified in the statements. And such respondents outnumbered those who declared themselves lacking the competencies. If we may, this B1 level can be categorized as a transition level.

At B2 level, which is the required level of competence, the total number of weiß nicht and nein answers far exceeded the $j a$ answers, i.e. 419 versus 188. This means that the majority of respondents $(37 \%)$ considered themselves did not have the competence level B2 and at least $24.7 \%$ (122) were in doubt whether they had the competencies as specified in the statements. Interestingly, there are two respondents who gave weiß nicht answers to whole statements representing B2 level competencies; there is no $j a$ or nein answers. It can be interpreted that the two respondents felt hesitant to all competencies at B2 level. Upon further examination, for the next level (C1), the same respondents provided nein answers to 6 out of $8(75 \%)$ statements. That is, these respondents felt no competence for $\mathrm{C} 1$ level. These answers are suitable (in line) with weiß nicht answers they gave at the B2 level.

At C1 level, most respondents considered themselves not having the competencies by providing nein answers to most statements, i.e. $171(45.9 \%)$. There are only $114 j a$ answers (30.6\%), and 87 weiß nicht answers (23.3\%). If given a strict line by taking only the $j a$ answers, it can be concluded that only about $30 \%$ of respondents perceived themselves to have the competence in this $\mathrm{C} 1$ level. The rest, about $70 \%$ felt that they had no competencies or were in hesitation. In fact, there are 5 respondents who explicitly provided nein answers to all items or statements of this level, which means that they were absolutely sure that they did not have any competencies specified in the statements.

Based on the discussion above, it can be argued that there is a reasonable trend that most or almost all of the respondents have a German language proficiency equivalent to A1 level, which is the lowest ability, then as the competencies get higher and higher, the less number of respondents are qualified for them. This indicates that respondents who have competencies at the $\mathrm{C} 1$ level will also have competence at the lower levels. On the other hand, the respondents who have A1 competencies do not necessarily have the competencies of the higher levels. All in all, it can be said that the majority of respondents, i.e. a total of 30 respondents $(65 \%)$, have the qualifications equivalent to B1 level. If this number is correlated with the competency standards set by the Department of German Language Education UNY, i.e. B2 level, the majority of respondents are currently under the required standard set by UNY. The number of respondents who meet the UNY standard (B2 level) is only 18 people (38.2\%), while those who can achieve over the UNY standard (C1 level) are 15 people (30.6\%).

The fact that more than half of the respondents $(65 \%)$ are only underqualified (B1 level) can be caused by some factors as follows. First, there is language attrition (Verlust der erworbenen Sprachkompetenzen), because the respondents who are high school teachers generally only teach German language at levels A1 and A2 (according to the Indonesian curriculum 
for high schools or SMA/SMK/MA). Their everyday environment also does not provide enough space and opportunities for the teachers to develop and mainly to use their German language skills. The langauge skills most widely used by the teachers are in the levels of A1 and A2. That is why their competencies at the higher level suffer attrition: due to not practicing it for quite a long time, the ability is then lost or diminished.

Second, considering that the GER / CEFR has just been established not quite a long time ago, and previously the German Language Education Department had not yet set a minimum standard of competence for its graduates, it is quite likely that graduates in the past were still below that B2 level. To ensure the quality of the graduates of UNY as one Institution for Teacher Education (LPTK) it is necessary to reinforce the standards of competence which refers to B2 level of CEFR. However, it is also necessary to compare these standards with other LPTKs both in Indonesia and overseas.

Third, many upgrading courses which are followed the respondents have not led to improved language skills in accordance with the CEFR. Fourth, the low participation of respondents in the joining language training or taking upgrading courses.

\section{B. Competencies of German Language Teachers in Vietnam}

The number of respondents participating in this study in Vietnam is only 8 people, which is far below the plan. This is because there was only one respondent taken from each of the eight regions. All respondents were given instrument (the questionnaire), like what was conducted to the respondents in Indonesia. Here are the results of the study in Vietnam.
Table 4. Respondent Self-Assessment based on Selbstevaluation Questionnaire who answered " $\mathrm{Ja}$ "

\begin{tabular}{lccccc}
\hline Niveau & A1 & A2 & B1 & B2 & C1 \\
\hline Frequency & 80 & 109 & 134 & 50 & 29 \\
\hline Total & 8 & 7.5 & 7 & 5 & 3.6 \\
\hline Percentage & $100 \%$ & $98 \%$ & $93 \%$ & $62.50 \%$ & $45.30 \%$ \\
\hline
\end{tabular}

Table 5. Respondent Self-Assessment based on Selbstevaluation Questionnaire who answered "Nein"

\begin{tabular}{lccccc}
\hline Niveau & A1 & A2 & B1 & B2 & C1 \\
\hline Frequency & 0 & 1 & 2 & 8 & 15 \\
\hline Total & 0 & 0.1 & 0.1 & 0.8 & 1.9 \\
Percentage & 0 & $0.90 \%$ & $1.30 \%$ & $10 \%$ & $23 \%$ \\
\hline
\end{tabular}

Table 6. Respondent Self-Assessment based on Selbstevaluation Questionnaire who answered "Weiß nicht"

\begin{tabular}{lccccc}
\hline Niveau & A1 & A2 & B1 & B2 & C1 \\
\hline Frequency & 0 & 1 & 8 & 22 & 20 \\
\hline Total & 0 & 0.1 & 0.4 & 2.2 & 2.5 \\
\hline Percentage & 0 & $0.90 \%$ & $5.50 \%$ & $27 \%$ & $31 \%$ \\
\hline
\end{tabular}

In table 4 above, all 8 respondents $(100 \%)$ stated that they have the competence A1 level. Followed then by the number repondents claimed to have competence of A2 level: 7.5 people (98\%), B1 level 7 people $(93 \%)$, B2 level 5 people $(62.50 \%)$, the highest ability or C1 level 3.6 people $(45.30 \%)$. The data indicate quite a fair trend as well, in which the number of respondents claiming to have the competencies is decreasing from a lower level to the higher level. This means that those who have the higher competence of $\mathrm{C} 1$ (highest) of course have the competencies of the lower levels. Conversely, those who have A1 (lowest) competencies do not necessarily have the competencies of higher levels.

In Table 5 we see the respondents who answered nein which means that the respondents were sure that they did 
not have the competency specified in the statement in the questionnaire. The details are as follows: A1 level 0 person $(0 \%), \mathrm{A} 2$ level 0.1 person $(0.9 \%)$, B1 level 0.1 person (1.30\%), B2 level 0.8 person (10\%), and C1 1.9 people $(23 \%)$. The data indicate that the higher the levels of ability, the greater the number of respondents who felt confident of not having such competencies specified in the statement.

Table 6 shows the respondents who answered weiß nicht, which means they were doubtful or might not understand the statements in the questionnaire. The details are as follows: A1 level 0 person $(0 \%)$, A2 level 0.1 person $(0.9 \%)$, B1 level 0.4 person $(5.50 \%)$, B2 level 2.2 people $(27 \%)$, and $\mathrm{C} 1$ level 2.5 people $(31 \%)$. The data indicates that the higher the levels of competence (C1), the greater the number of respondents who were hesitant or did not understand the statements in the questionnaire.

\section{Comparison of German Language Teacher Competencies in Vietnam and Indonesia}

As has been mentioned above, the measurement or level of proficiency in German language according to CEFR for Language consists of six levels, from A1 (the lowest), to A2, B1, B2, C1, and C2 (the highest). To provide a clearer picture of the perception of German language teachers in Vietnam for their professional competence, the data obtained will be discussed based on each level and at the same time compared with the results of the research in Indonesia.

Data of Indonesian respondents who answered ' $J a^{\prime}$

\begin{tabular}{lccccc}
\hline Niveau & A1 & A2 & B1 & B2 & C1 \\
\hline Frequency & 459 & 569 & 566 & 188 & 114 \\
\hline Total & 46 & 40 & 31 & 18 & 15 \\
\hline Percentage & $95.6 \%$ & $84.6 \%$ & $65.5 \%$ & $38.2 \%$ & $30.6 \%$ \\
\hline
\end{tabular}

Data of Vietnamese respondents who answered ' $J a^{\prime}$

\begin{tabular}{lccccc}
\hline Niveau & A1 & A2 & B1 & B2 & C1 \\
\hline Frequency & 80 & 109 & 134 & 50 & 29 \\
\hline Total & 8 & 7.5 & 7 & 5 & 3.6 \\
\hline Percentage & $100 \%$ & $98 \%$ & $93 \%$ & $62.50 \%$ & $45.30 \%$ \\
\hline
\end{tabular}

Level A1 is the lowest level in German language skills. All respondents from Vietnam stated very confidently to have passed this competency level. This is demonstrated by the data that $100 \%$ of respondents claimed to be at this level. Compared with data from Indonesia, the respondents from Vietnam are in a better position because only $95.6 \%$ of Indonesian respondents stated to have passed this level. Thus it is possible that some teachers from Indonesia were not sure to be in this level.

At level A2, 84.6\% respondents from Indonesia claimed to be in this level, compared to $98 \%$ respondents from Vietnam who stated so. These data indicate that more German language teachers from Vietnam are at this level than those from Indonesia.

At the next level, i.e. Level B1, there are $65.5 \%$ respondents from Indonesia who claimed to be in this level, whereas 93\% respondents from Vietnam stated to be in this level. Similarly, these data also indicate that more German language teachers from Vietnam are at this B1 level than those from Indonesia.

At level B2, there are $30.6 \%$ of the Indonesian respondents who stated that they were in this level, whereas $62.50 \%$ respondents from Vietnam claimed to be in this level. Again, in comparison, it also indicates that more German language teachers from Vietnam are at this B2 level than the German teachers from Indonesia.

At level C1, 38.2\% Indonesian respondents stated that they were in this level, compared to $45.30 \%$ respondents from Vietnam who expressed themselves 
to be in this level. It also shows that more German language teachers from Vietnam claimed to be at this level than the German teachers from Indonesia.

On average, we can say that German language teachers in Vietnam are one level higher in language competencies that German language teachers in Indonesia. This conclusion is drawn from the data showing that respondents from Vietnam are at B2 level while respondents from Indonesia are at the level of B1.

\section{CONCLUSION}

Several conclusions can be drawn from this study: Firstly, the level of competencies of German language teachers in Vietnam is at level B2 while that of German language teachers in Indonesia is one level lower, i.e. at level B1.

Secondly, there is language attrition (Verlust der erworbenen Sprachkompetenzen) occurring in German teachers in Indonesia, because the respondents who teach in high schools generally only teach German language at levels A1 and A2 (according to the curriculum of SMA/SMK/MA). The daily environment they encounter does not provide enough challenge and opportunities for the teachers to develop or at least use the higher language skills they have actually possessed. The skills that are most widely used by teachers are those at the levels A1 and A2. That is why competence at the level above it suffered attrition, meaning that due to the lack of practice the skill is then lost or diminished.

Thirdly, since the Common European Framework of Reference (CEFR) has just been established and previously the German Language Education Department UNY had not explicitly set a minimum standard of competence, it is possible that graduates in the past did not achieve the recent required level. To ensure the quality of the graduates of the Institute of Teacher Education (LPTK) it is necessary to reinforce the standards of competence which refers to the CEFR, i.e. level B2. However, it is also necessary to compare these standards with other LPTKs across Indonesia as well as abroad.

Some suggestions from the results of this study: First, it needs a comparative study concerning the German language learning process in Vietnam National University of Hanoi and in Yogyakarta State University. Second, the government needs to provide intensive language trainings that refer to the CEFR for German language teachers. Third, it is necessary to organize a joint international meeting for German language teachers from Indonesia and Vietnam.

This study has some limitations, namely the survey method used here was just in the form of a written questionnaire, not a test instrument. Consequently, the gathered data were just in the form of perception given by respondents concerning their German language competencies. It would be better to have a further research in the form of the German language proficiency test in order to confirm whether or not their perceptual proficiency are in accordance with the actual competencies.

\section{ACKNOWLEDGEMENTS}

This study is the result of an international collaborative research funded by the Faculty of Languages and Arts, Yogyakarta State University (UNY). Therefore, the researchers would like to express their sincere gratitude to the Faculty of Languages and Arts UNY for funding this collaborative research with Vietnam National University of Hanoi.

\section{BIBLIOGRAPHY}

Glück, Helmut \& Sauer, Wolfgang Werner. 1997. Gegenwartsdeutsch. Stuttgart: Verlag J.B. Metzler.

Grum, Urška. 2012, Mündliche Sprachkompetenzen Deutschsprachiger 
Lerner des Englischen. Entwicklung eines Kompetenzmodells zur Leistungsheterogenität. Frankfurt a.M. et al: Lang (Kolloquium Fremdsprachenunterricht, 45). ISBN 978-3-631-62306-0. 372 Seiten, 54.80 Euro.

Jones, N., \& Saville, N. 2009. European Language Policy: Assessment, Learning, And The Cefr. Annual Review of Applied Linguistics, 29, 51-63. doi: http://dx.doi. org/10.1017/S0267190509090059

Kirchner, Hildegard. 2002. Umsetzung der Eurodidaktik des Gemeinsamen Europäischen Referenzrahmens in den Sprachkursen der Goethe-Institute in Deutschland. Gfl-journal, No. 3/2002.
Little, D. 2006. "The Common European Framework of Reference for Languages: Content, Purpose, Origin, Reception and Impact. Language Teaching, 39(3),167-190. Retrieved http://search.proquest.com/docview/ 217743530 ? accountid $=31324$

Undang-undang Nomor 20 tahun 2003 tentang Sistem Pendidikan Nasional

Widodo, Pratomo. 2011. Germanistik dan Profesionalitas Guru Bahasa Jerman. Pidato Pengukuhan Guru Besar pada Rapat Terbuka Senat Universitas Negeri Yogyakarta. 